Dinesh Bhatia 1,2, S.K. Sinha²

1 Jawahar Lal Nehru Govt. Engineering College, Department of Textile Engineering, Sundernagar (Himachal Pradesh), India

2 Dr. B.R. Ambedkar National Institute of Technology, Department of Textile Technology, Jalandhar (Punjab), India

\title{
Thermo-physiological Properties of Structurally Modified Wool/Polyester Blended Machine and Hand-Spun Yarns as a Weft in Handloom Fabrics
}

\author{
Lastnosti toplotne udobnosti ročno stkanih tkanin z votkom \\ iz strukturno modificirane preje iz mešanice volna/poliester, \\ izdelanim strojno in ročno
}

\section{Original scientific article//zvirni znanstveni članek}

Received/Prispelo 4-2020 • Accepted/Sprejeto 5-2020

\begin{abstract}
An attempt was made to compare the combined desirability value for a treated and untreated handloom fabric using machine-spun and hand-spun blended yarns as weft. The experimental plan included the preparation of both hand-spun and machine-spun yarns at different blend compositions according to a mixture design prepared on Design-Expert software, followed by the preparation of fabric on a handloom. The dissolution of one component using a suitable chemical treatment was then performed on both fabrics made from handspun and machine-spun yarn by taking into account an expected significant change in the arrangement of constituent fibres that ultimately enhance performance in terms of the thermo-physiological behaviour of fabrics. All properties viz air permeability, compressibility, thermal resistance, water vapour permeability, bending rigidity and drying capacity showed significant differences for both type of fabrics. Fabrics with hand-spun yarn as a weft demonstrated higher values of thermal resistance, compressibility, water vapour permeability and drying capacity due to the voluminous and soft structure of hand-spun yarn compared to fabric with machine-spun yarn as a weft. In general, after the dissolution of the polyvinyl alcohol component, both types of fabrics exhibited higher values of thermal resistance, compressibility, drying capacity and water vapour permeability, while values for air permeability and bending rigidity were lower for untreated fabrics. The results of the optimisation of treated fabrics with machine-spun yarn as weft demonstrated the highest desirability value (0.73), as well as a lower percentage of wool fibres (55\%), followed by treated fabrics with hand-spun yarn as weft, which demonstrated a desirability value of 0.66 and a percentage of wool fibres of $60 \%$ in the blend composition. Untreated fabrics (both machine-spun and hand-spun) exhibited a similar desirability value and at same blend composition (20\% polyester, $70 \%$ wool and $10 \%$ polyvinyl alcohol).
\end{abstract}

Keywords: desirability, optimisation, blend composition, PVAL, handloom, thermal resistance

\section{Izvleček}

Neobdelane in obdelane ročno stkane tkanine z votkom iz strojno in ročno izdelanih mešanih prej so bile primerjane z vidika kombiniranega indeksa zaželenosti. Eksperimentalni načrt vključuje pripravo ročno in strojno spredene preje iz mešanic različne sestave glede na načrt, zasnovan s pomočjo programskega orodja Design-Expert, ki mu je sledila izdelava tkanin na ročnih statvah. Obe vrsti tkanin, izdelanih z ročno oziroma strojno spredeno prejo v votku, so bile kemično obdelane, pri čemer se je raztopila ena komponenta, da bi dosegli pričakovano spremembo razporeditve 
vsebovanih vlaken, ki znatno izboljšajo toplotno udobje tkanin pri nošenju. Vse lastnosti, tj. zračna prepustnost, stisljivost, toplotni upor, prepustnost vodne pare, upogibna togost in kapaciteta sušenja, kažejo na velike razlike med obema vrstama tkanin. Zaradi voluminozne in mehke strukture ročno spredene votkovne preje so imele tkanine, ki so to prejo vsebovale, višje vrednosti toplotnega upora, stisljivosti, prepustnosti vodne pare in so se sušile hitreje v primerjavi s tkaninami, ki so vsebovale strojno spredeno votkovno prejo. Na splošno sta po raztopitvi komponente polivinilnega alkohola obe vrsti tkanin pokazali višje vrednosti toplotnega upora, stisljivosti, sposobnosti sušenja in prepustnosti vodne pare in nižje vrednosti zračne prepustnosti in upogibne togosti v primerjavi z neobdelanimi tkaninami. Rezultati optimizacije za obdelane tkanine, ki so vsebovale strojno spredeno votkovno prejo, kažejo najvišjo indeks zaželenosti $(0,73)$ pri najnižji vsebnosti volne $(55 \%)$, sledijo obdelane tkanine z ročno spredeno prejo v votku $(0,66)$ in $60 \%$ volnenih vlaken $v$ mešanici. Neobdelane tkanine (s strojno in ročno spredeno votkovno prejo) so imele skoraj podobni indeks zaželenosti in enako mešanico (20\% poliestra, 70 \% volne in $10 \%$ polivinil alkohola). Ključne besede: zaželenost, optimizacija, sestava mešanice, PVAL, ročne statve, toplotni upor

\section{Introduction}

The handloom industry is one of the oldest and largest cottage industry in India,which represents and preserves the vibrant culture of India. Due to the use of less capital and power, their eco-friendly behaviour and their suitability for innovation and transformation with respect to market requirements, handloom fabrics provide a broader scope for research and innovation. Comfort is considered one of the fundamental properties for evaluating any textile material. Comfort is defined as "the absence of unpleasantness or discomfort" or "a natural state compared to the mere active state of pleasure". Handloom fabrics are more comfortable due to the specific behaviour of handloom fabric and the structure of hand-spun yarn because the structure of yarn and fabric plays an important role in the comfort of any fabric.

Thermo-physiological wear comfort, which relates to the heat and moisture transport properties of clothing and the way that clothing helps to maintain the heat balance of the body during various activities, is one of the basic and necessary properties of a fabric. Any change in the structure of yarn and fabric helps to improve comfort in terms of heat and moisture, as it plays important role in the comfort of any fabric. Thus, many researchers attempt to identify different methods by which the structure of yarn and fabric can be altered to improve comfort properties. The nature, composition and arrangement of constituent fibres, through the dissolving of one component, can influence the structure, properties and performance of yarn, which may ultimately influence fabric comfort properties [1-6]. Mixture experiments are a special class of response surface experiments in which the product under investigation is made up of several components or ingredients [7]. This design is thus suitable in a situation where the response is a function of the proportions of the different ingredients in the mixture [8].

During the twenty-first century, clothing markets have become highly competitive due to high demand and changing fashion. The textile and clothing industries are searching for competitive advantages by understanding and meeting consumer needs and desires in order to survive on the rapidly changing, highly competitive clothing market. Different statistical techniques are developed by researchers to satisfy the needs of industries. These include response surface methodology and various optimisation algorithms, e.g. the desirability function-based approach [9-10], multiple regression and linear programming-based approaches [11], and utility function-based approach [12]. Among the above, the desirability function-based approach has gained the most popularity in solving optimisation problems. Ghosh et al. [13] optimised different comfort and safety properties using the desirability function to achieve an overall desirability varying from zero to one. Gupta et al. [14] used the desirability approach to optimise carpet durability by considering abrasion loss, compression and compression recovery as a single objective. Knitted fabric properties, such as areal density, bursting pressure, extensibility, dimensional stability and abrasion resistance, were optimised using the desirability function [15]. Asim et al. [16] estimated the fixation of reactive printing and crease-resistant finishing using the desirability function.

The disappearance of traditional textiles, through globalisation due to a lack of seriousness in this

Tekstilec, 2020, 63(2), 138-150 
field, has again prompted researchers to improve the quality of these fabrics through different product development to compete on the highly competitive market of power loom fabrics.

The present work involved a detailed study of all the important fabric comfort properties of handloom fabrics made of the same warp yarn and different filling (for both machine- and hand-spun), which were produced according to a mixture design from different percentages of wool, polyester and PVAL. The optimisation of different fabric properties was preformed using the desirability function.

\section{Experimental}

\subsection{Materials}

Merino wool (19.5 $\mu \mathrm{m}, 70 \mathrm{~mm})$, polyester (2 dtex, $52 \mathrm{~mm}$ ) and polyvinyl alcohol (PVAL; $1.44 \mathrm{dtex}$, $44 \mathrm{~mm}$ ) fibres were blended on a gill box in different proportions according to a mixture design.

Table 1: Levels and factors are given below

\begin{tabular}{|l|c|c|c|}
\hline \multicolumn{1}{|c|}{ Factors } & Low & Medium & High \\
\hline Polyester (\%) & 20 & 40 & 60 \\
\hline $\begin{array}{l}\text { Merino wool } \\
\text { (\%) }\end{array}$ & 30 & 50 & 70 \\
\hline PVAL (\%) & 10 & 15 & 20 \\
\hline
\end{tabular}

Table 2: Mixture design used to produce different blend proportions of yarn

\begin{tabular}{|c|c|c|c|}
\hline S. No. & $\begin{array}{c}\text { Polyester } \\
(\%)\end{array}$ & $\begin{array}{c}\text { Merino wool } \\
(\%)\end{array}$ & $\begin{array}{c}\text { PVAL } \\
(\%)\end{array}$ \\
\hline S1 & 35 & 45 & 20 \\
\hline S2 & 20 & 60 & 20 \\
\hline S3 & 20 & 65 & 15 \\
\hline S4 & 20 & 70 & 10 \\
\hline S5 & 55 & 30 & 15 \\
\hline S6 & 40 & 50 & 10 \\
\hline S7 & 60 & 30 & 10 \\
\hline S8 & 40 & 50 & 10 \\
\hline S9 & 20 & 70 & 10 \\
\hline S10 & 60 & 30 & 10 \\
\hline S11 & 60 & 30 & 10 \\
\hline S12 & 50 & 30 & 20 \\
\hline
\end{tabular}

Twelve wool/polyester/PVAL blended yarn samples, with a nominal linear density 50 tex $(20 \mathrm{Nm})$, were prepared on a worsted spinning system. Another set of twelve yarns of the same linear density were also prepared on charkha (hand-spun yarns). A mixture design (Table 2) was used to investigate the proportion of different fibres on various properties of yarn. The idea of using a mixture design is to study the effect of the proportion of different fibres, and to set the proportion of the fibres according to the end-product with limited numbers of samples. The levels and percentages of different fibres are presented in Table 1.

\subsection{Fabric formation}

Twenty-four fabric samples were prepared on a handloom by varying weft yarns (twelve from machinespun and twelve from hand-spun yarn) and keeping warp yarn constant for all the fabrics. BT and BTH denote fabrics before treatment with machine-spun and hand-spun weft yarn respectively, while AT and ATH denote fabrics after treatment with machinespun and hand-spun weft yarn respectively.

\subsection{Dissolution of PVAL fibre on fabric stage}

After the production of fabrics, PVAL was removed by treating the fabrics (that contain PVAL in their filling yarn) with $0.5 \%$ formic acid at $90{ }^{\circ} \mathrm{C}$ for 60 minutes, followed by a hot wash. All fabric samples were then dried in an oven, followed by conditioning for 24 hours under standard atmospheric conditions to achieve standard moisture conditions.

\subsection{Test methods}

The prepared samples were conditioned and tested for different fabric properties according to the standard mentioned below. Air permeability was measured using a TEXTEST FX 3300 air permeability tester according to the BS 5636 standard. Water vapour permeability (WVP) was measured according to the BS 7209 standard. Permeability was calculated using equation 1 .

$W V P=\frac{24 m}{\mathrm{~A} \times t}\left(\mathrm{~g} \mathrm{~m}^{-2} 24^{-1} \mathrm{~h}^{-1}\right)$

where, $m$ represents loss in mass (g), $A$ represents the open area of the dish $\left(\mathrm{m}^{2}\right)$ and $t$ represents the time between weighing $(\mathrm{h})$.

For the purpose of testing drying capacity, 12 circular specimens per sample were cut using a round-shaped 
cutter, each with an area of $100 \mathrm{~cm}^{2}$. Specimens were conditioned at a standard atmosphere for 6 hours as per ASTM D 1776 and the weight of each sample $\left(W_{1}\right)$ was recorded. The samples were dipped in distilled water to a depth of around $10 \mathrm{~cm}$ with the help of a wire sinker. After 6 hours, the specimens were taken out and kept on a sponge sheet to dry in a closed room where there was no air movement. A tropical atmosphere room temperature $\left(27^{\circ} \mathrm{C} \pm 2{ }^{\circ} \mathrm{C}\right)$ and relative humidity $(65 \% \pm 2 \%)$ were maintained during the test. All fabrics were kept under the same conditions and the face side of the specimens was kept up. After a fixed time (i.e. 10 hours), the weight $\left(W_{2}\right)$ of specimens was taken for all samples. Drying capacity was calculated by using equation 2 .

Drying capacity $=$

$=\left(W_{2}-W_{1}\right) \times 100\left(\mathrm{~g} \mathrm{~m}^{-2} 10^{-1} \mathrm{~h}^{-1}\right)$

where $W_{1}$ represents the weight of the specimen (g) and $W_{2}$ represents the weight of water $(\mathrm{g})$ dried from the fabric per $100 \mathrm{~cm}^{2}$ in $10 \mathrm{~h}$.

The test to determine fabric stiffness was carried out according to ASTM D1388-33 using a stiffness tester. Before the tests, the samples were conditioned under laboratory conditions $\left(27 \pm 2{ }^{\circ} \mathrm{C}, 65 \pm 2 \%\right.$ relative humidity (RH)). The tests were performed on each fabric sample at five replicas in both the warp and weft directions. Equation 3 given below was used to calculate the bending rigidities in the warp and weft directions. Overall fabric bending rigidity was calculated using equation 4 .

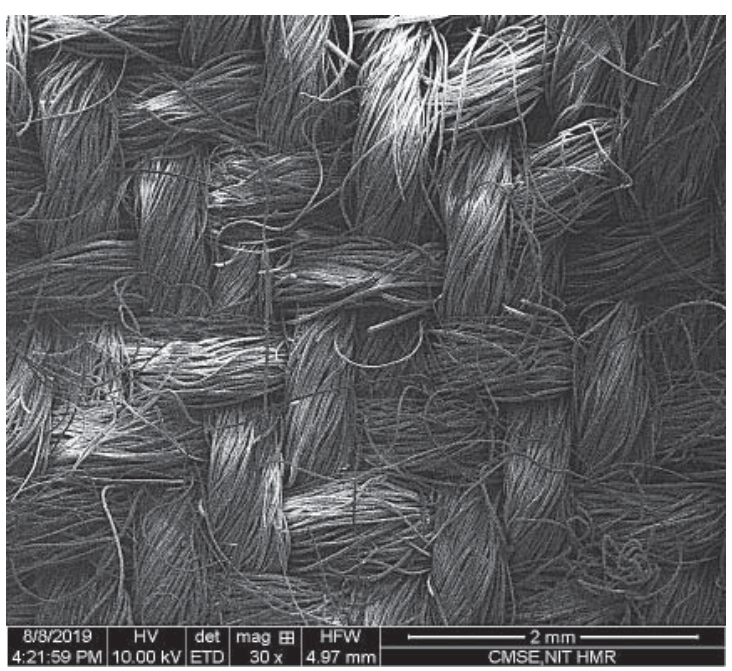

a)
Thermo-physiological Properties of Structurally Modified Wool/ Polyester Blended Machine and Hand-Spun Yarns as a Weft in Handloom Fabrics

$G=9.807 \times 10^{-6} W c^{3}$

where, $G$ represents the fabric bending rigidity $(\mu \mathrm{Nm})$ and $W$ represents the mass per unit area $\left(\mathrm{g} \mathrm{m}^{-2}\right)$, while the bending length $c$ is equal to half the length of the overhang $(\mathrm{mm})$.

$G_{o}=\left(G_{w} G_{f}\right)^{\frac{1}{2}}$

where, $G_{o}$ represents the overall fabric bending rigidity, $G_{w}$ represents the warp bending rigidity and $G_{f}$ represents the weft bending rigidity.

To measure compressibility, the thickness of the fabric was measured using a thickness gauge at pressures of $20 \mathrm{~g} \mathrm{~cm}^{-2}$ and $50 \mathrm{~g} \mathrm{~cm}^{-2}$. The compressibility of the fabric was then calculated using equation 5 :

Compressibility $=\left[\frac{T_{20}-T_{50}}{T_{20}}\right] \times 100(\%)$

where $T_{20}$ and $T_{50}$ represent the thickness of fabric measured using a thickness gauge at pressures of $20 \mathrm{~g} \mathrm{~cm}^{-2}$ and $50 \mathrm{~g} \mathrm{~cm}^{-2}$ respectively.

The thermal resistance of fabric was measured on a Testex guarded hot plate thermal conductivity tester. A minimum of three observations were carried out to determine the average CLO value.

\section{Results and discussion}

\subsection{Observed structural changes}

SEM images of untreated and treated fabric are shown in Figures 1-4. Figure 1 and Figure 3 show a

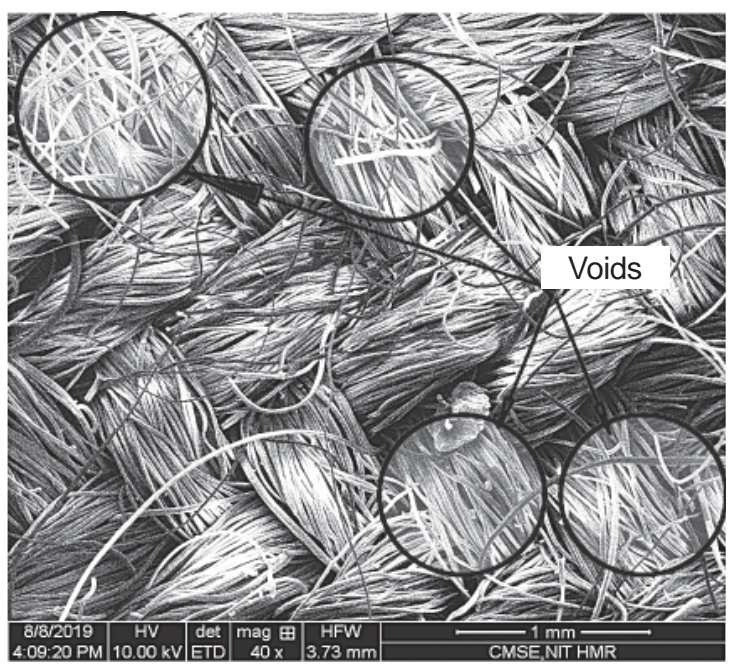

b)

Figure 1: Scanning electron microscope images: a) S4 BT and b) S4 AT 


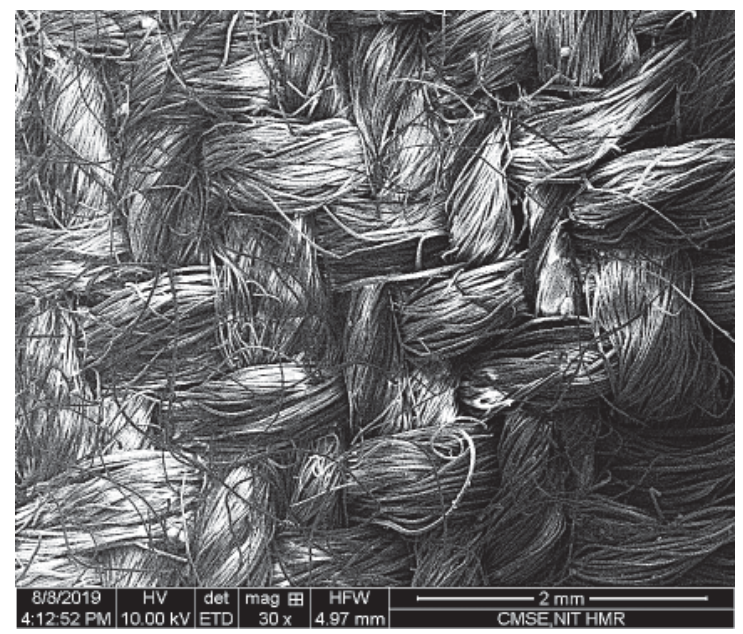

a)

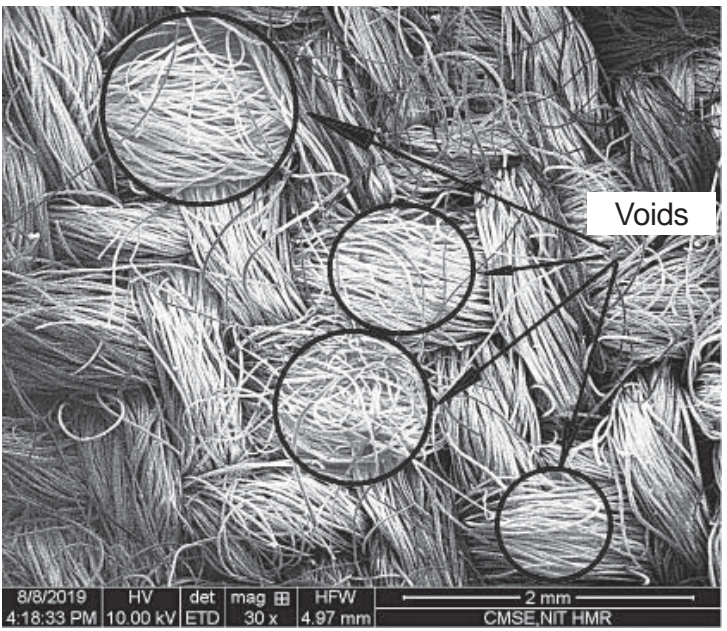

b)

Figure 2: Scanning electron microscope images: a) S4 ATH and b) S4 BTH

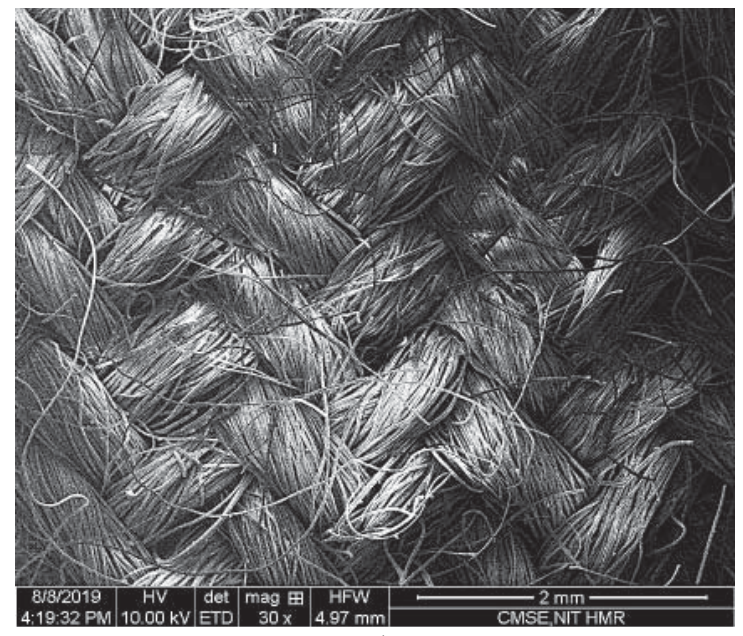

a)

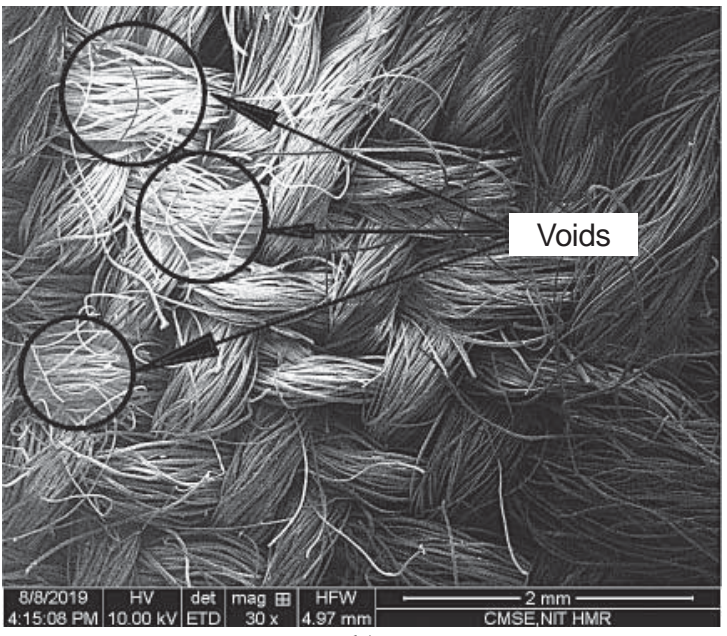

b)

Figure 3: Scanning electron microscope images: a) S7 BT and b) S7 AT

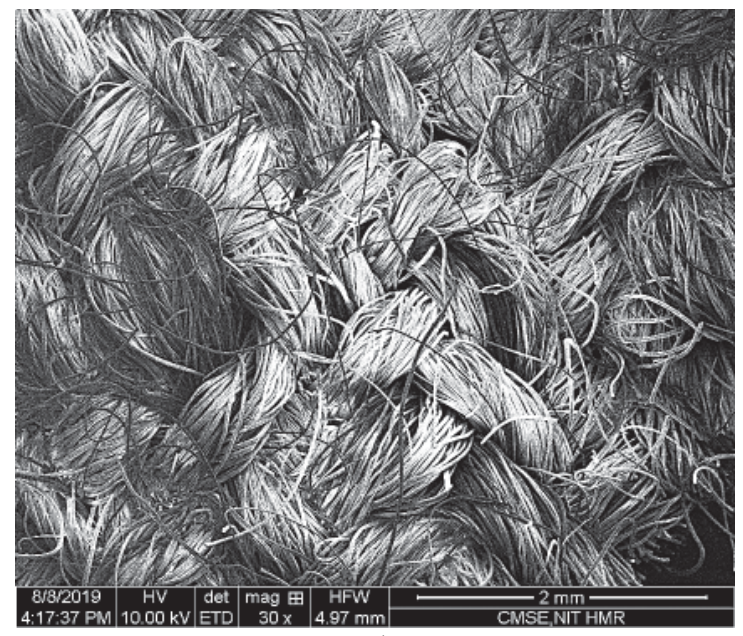

a)

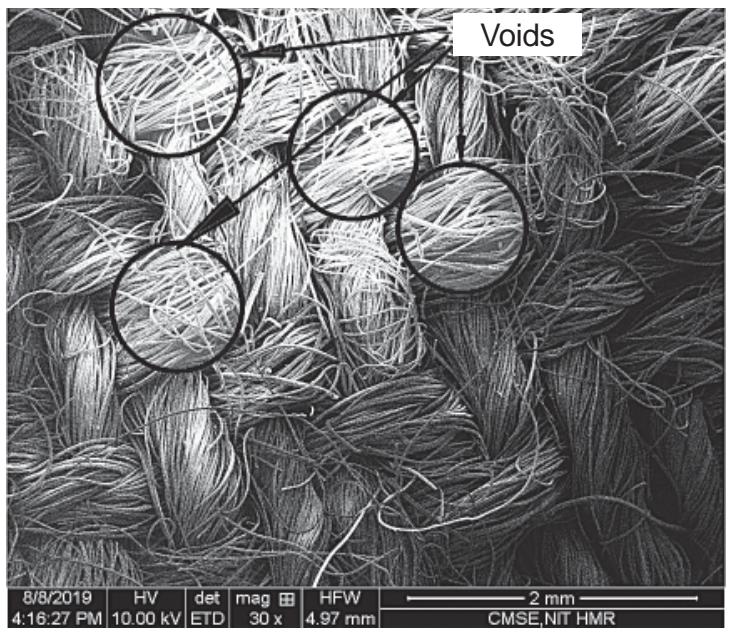

b)

Figure 4: Scanning electron microscope images: a) S7 ATH and b) S7 BTH 
fabric with maximum wool content with machinespun and hand-spun yarn as a weft respectively, while Figure 2 and Figure 4 show a fabric with maximum polyester content with machine-spun and hand-spun yarn as a weft respectively.

The following observations can be made from the images:

(a) The removal of the PVAL component led the creation of voids in the structure of fabric.

(b) The treatment of fabric with hand-spun yarn as a weft created more voids than fabric with machine-spun yarn as a weft.

(c) More voids were observed in fabric with weft yarn with a higher percentage of wool after the dissolution of the PVAL component than in fabric with weft yarn with a lower wool content.

The creation of voids after the dissolution of the PVAL component influences the arrangement and configuration of fibres in yarns. This change in the arrangement and configuration of fibres in yarn and fabric ultimately influences the thermo-physiological characteristics of fabric.

\subsection{Properties of fabrics}

Table 3 shows the physical properties of fabrics, such as the weight per unit area, thickness, thread density and yarn linear density of both treated and untreated fabrics for hand-spun and machine-spun yarns as weft.
Table 4 shows properties related to the thermophysiological behaviour of both treated and untreated fabrics with machine- and hand-spun yarns as a weft.

\section{Thermal resistance}

The experimental results of thermal resistance (CLO value) are presented in Table 4 for both treated and untreated fabrics containing both hand- and machine-spun yarns as a weft at different blend compositions.

It is evident from Figure 5 that the CLO value is higher for fabrics containing hand-spun yarn than for fabrics that contain machine-spun yarn as a weft. Air entrapment is one of the major reasons for the enhancement of the thermal resistance of any fabric. Hand-spun yarn is voluminous and soft, which helps to make bulkier fabric than machinespun yarn, which helps to entrap more air, resulting in a higher value of thermal resistance in terms of a higher CLO value.

As shown in Figure 5, the thermal resistance of treated fabric (for both machine- and hand-spun yarn) is higher than that of untreated fabric. After the dissolution of the PVAL component, the diameter of the yarn increased causing the creation of pores in the structure, which helps in the entrapment of air, resulting in a higher CLO value for treated fabrics than for untreated fabrics.

Table 3: Physical properties of fabrics before and after treatment (weft from both hand-and machine-spun yarns)

\begin{tabular}{|c|c|c|c|c|c|c|c|c|c|c|c|c|c|c|}
\hline \multirow{2}{*}{$\begin{array}{c}\text { Seq. } \\
\text { no }\end{array}$} & \multicolumn{4}{|c|}{$\begin{array}{l}\text { Mass per unit area } \\
\qquad\left(\mathrm{g} \mathrm{m}^{-2}\right)\end{array}$} & \multicolumn{4}{|c|}{ Thickness (mm) } & \multicolumn{4}{|c|}{ EPI/PPI } & \multicolumn{2}{|c|}{$\begin{array}{c}\text { Linear density }(\mathrm{Nm}) \\
\text { warp/weft yarns }\end{array}$} \\
\hline & BT & AT & BTH & ATH & $\mathrm{BT}$ & AT & BTH & ATH & $\mathrm{BT}$ & $\mathrm{AT}$ & BTH & ATH & BT & BTH \\
\hline S1 & 190 & 180 & 185 & 178 & 0.58 & 062 & 0.59 & 0.64 & $48 / 50$ & $46 / 48$ & $48 / 51$ & $46 / 48$ & $30.2 / 20.5$ & $30.2 / 20.4$ \\
\hline $\mathrm{S} 2$ & 175 & 170 & 174 & 168 & 0.64 & 67 & 0.65 & 0.70 & $49 / 51$ & $47 / 49$ & $49 / 51$ & $47 / 49$ & $30.2 / 20.4$ & $30.2 / 20.5$ \\
\hline S3 & 178 & 170 & 173 & 165 & 0.67 & 69 & 0.65 & 0.70 & $50 / 51$ & $46 / 47$ & $50 / 51$ & $46 / 47$ & & $30.2 / 20.4$ \\
\hline S4 & 170 & 159 & 168 & 154 & 0.66 & 0.07 & 0.64 & ח7 & $48 / 53$ & $47 / 48$ & $48 / 52$ & $47 / 48$ & $30.2 / 20.3$ & $30.2 / 20.4$ \\
\hline S5 & 176 & 164 & 174 & 163 & 0.55 & 0.59 & 0.57 & 0.61 & $50 / 52$ & $47 / 50$ & $50 / 52$ & $47 / 50$ & $30.2 / 20.3$ & $30.2 / 20.4$ \\
\hline S6 & 183 & 175 & 182 & 173 & 0.57 & 0.60 & 0.59 & 0.63 & $48 / 53$ & $47 / 51$ & $48 / 53$ & & $30.2 / 20.4$ & $30.2 / 20.3$ \\
\hline S7 & 182 & 172 & 180 & 172 & 0.55 & 0.50 & 0.57 & 0.59 & $50 / 49$ & $48 / 47$ & $50 / 49$ & $48 / 47$ & $30.2 / 20.4$ & $30.2 / 20.4$ \\
\hline S8 & 185 & 179 & 180 & 172 & 0.57 & & & 0.63 & $53 / 52$ & $51 / 51$ & $53 / 52$ & $51 / 51$ & $30.2 / 20.2$ & $30.2 / 20.3$ \\
\hline S9 & 168 & 160 & 165 & 158 & 0.65 & & 0.67 & 0.71 & $48 / 52$ & $47 / 51$ & $48 / 52$ & $47 / 51$ & $30.2 / 20.2$ & $30.2 / 20.4$ \\
\hline S10 & 182 & 174 & 178 & 170 & 0.55 & 0.57 & 0.56 & 0.60 & $50 / 51$ & $50 / 49$ & $49 / 51$ & $50 / 49$ & $30.2 / 20.3$ & $30.2 / 20.4$ \\
\hline S11 & 181 & 172 & 178 & 171 & 0.54 & 0.57 & 0.56 & 0.60 & $50 / 51$ & $49 / 50$ & $50 / 51$ & $49 / 50$ & $30.2 / 20.4$ & $30.2 / 20.3$ \\
\hline $\mathrm{S} 12$ & 180 & 169 & 178 & 168 & 0.55 & 0.57 & 0.58 & 0.61 & $50 / 51$ & $49 / 50$ & $49 / 51$ & $49 / 50$ & $30.2 / 20.5$ & $30.2 / 20.4$ \\
\hline
\end{tabular}


Table 4: Fabric properties before and after treatment (weft from both hand-and machine-spun yarns)

\begin{tabular}{|c|c|c|c|c|c|c|c|c|c|c|c|c|}
\hline \multirow{2}{*}{$\begin{array}{l}\text { S. } \\
\text { No. }\end{array}$} & \multicolumn{4}{|c|}{$\begin{array}{l}\text { Thermal resistance } \\
\text { (CLO) }\end{array}$} & \multicolumn{4}{|c|}{$\begin{array}{c}\text { Compressibility } \\
(\%)\end{array}$} & \multicolumn{4}{|c|}{$\begin{array}{l}\text { Air permeability } \\
\left(\mathrm{cm}^{3} \mathrm{~cm}^{-2} \mathrm{~s}^{-1}\right)\end{array}$} \\
\hline & BT & $\mathrm{AT}$ & BTH & ATH & BT & $\mathrm{AT}$ & BTH & ATH & BT & $\mathrm{AT}$ & BTH & ATH \\
\hline S1 & 0.14 & 0.20 & 0.16 & 0.21 & 16.27 & 25.34 & 20.24 & 27.78 & 35.12 & 28.14 & 32.12 & 25.14 \\
\hline S2 & 0.16 & 0.21 & 0.18 & 0.22 & 18.98 & 26.62 & 22.41 & 28.24 & 36.01 & 29.12 & 34.11 & 28.47 \\
\hline S3 & 0.16 & 0.21 & 0.18 & 0.22 & 19.14 & 27.22 & 23.14 & 29.45 & 36.92 & 30.22 & 33.45 & 29.15 \\
\hline S4 & 0.17 & 0.20 & 0.18 & 0.21 & 20.94 & 28.05 & 24.20 & 30.25 & 38.25 & 31.25 & 35.21 & 29.78 \\
\hline S5 & 0.14 & 0.18 & 0.16 & 0.19 & 13.23 & 17.95 & 17.25 & 20.10 & 27.35 & 20.95 & 24.78 & 20.12 \\
\hline S6 & 0.15 & 0.18 & 0.16 & 0.20 & 15.67 & 22.46 & 19.47 & 24.58 & 30.66 & 25.16 & 27.22 & 24.14 \\
\hline S7 & 0.14 & 0.19 & 0.16 & 0.21 & 12.75 & 16.62 & 16.78 & 18.89 & 26.02 & 19.22 & 23.92 & 19.14 \\
\hline S8 & 0.15 & 0.18 & 0.17 & 0.19 & 17.27 & 22.81 & 21.62 & 24.78 & 32.41 & 25.51 & 29.33 & 24.18 \\
\hline S9 & 0.16 & 0.19 & 0.18 & 0.20 & 20.13 & 26.94 & 24.18 & 28.45 & 36.22 & 29.92 & 33.62 & 28.46 \\
\hline S10 & 0.14 & 0.18 & 0.16 & 0.20 & 12.71 & 16.34 & 16.98 & 18.78 & 26.3 & 19.3 & 23.14 & 19.13 \\
\hline S11 & 0.14 & 0.18 & 0.16 & 0.20 & 12.56 & 15.98 & 16.89 & 18.90 & 25.22 & 18.92 & 22.7 & 18.27 \\
\hline S12 & 0.14 & 0.20 & 0.16 & 0.21 & 11.48 & 18.67 & 15.24 & 17.49 & 27.97 & 21.77 & 24.87 & 20.47 \\
\hline
\end{tabular}

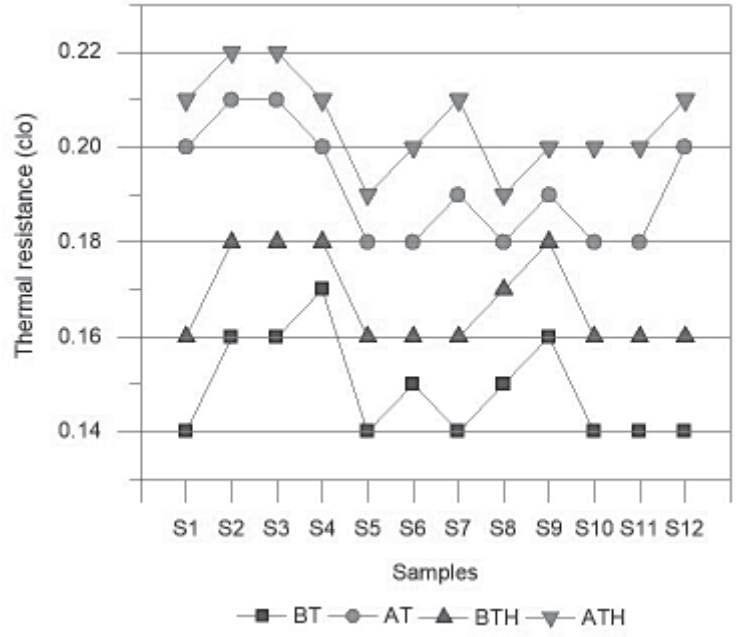

Figure 5: Thermal resistance of fabrics

\section{Compressibility}

The compressibility of any fabric is influenced by its bulkiness and thickness. Bulkier and thicker fabric compresses more easily than less bulky and thinner fabric. Figure 6 shows the compressibility for all fabrics in the treated and untreated stages. It was determined that fabric with hand-spun yarn compresses more easily than fabric with machine-spun yarn as a weft. Due to the structural differences and higher bulk of hand-spun yarn, the fabrics are spongier that fabrics with machine-spun yarn as a weft. Thus, fabrics from hand-spun yarn are bulkier, which leads to the higher compression value of the fabric.
This study also found that treated fabric shows a higher compression than untreated fabric, for both fabrics with machine- and hand-spun yarn as a weft, as shown in Figure 6. After the dissolution of the PVAL component, pores developed in the yarn structure, which ultimately led to a reduction in the compactness of fabric. Thus, the compression of treated fabric increased after the dissolution of the PVAL component.

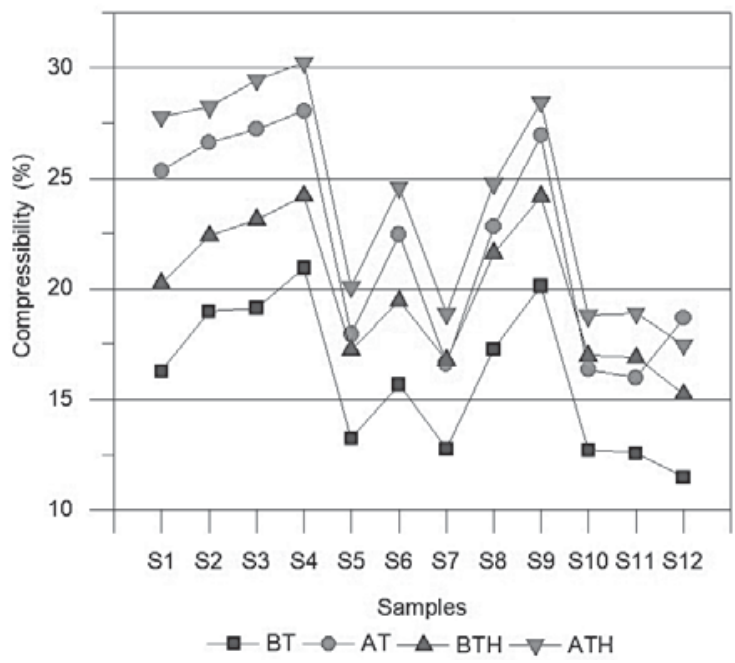

Figure 6: Compressibility of fabrics

\section{Air permeability}

The air permeability of fabric depends on the inter and intra yarn pores, and the hairiness of the yarn used in a fabric. Hand-spun yarns are voluminous 


\begin{tabular}{|c|c|c|c|c|c|c|c|c|c|c|c|c|}
\hline & \multicolumn{9}{|c|}{$\begin{array}{c}\text { Water vapour permeability } \\
\left(\mathrm{g} \mathrm{m}^{-2} 24^{-1} \mathrm{~h}^{-1}\right)\end{array}$} & \multicolumn{3}{c|}{$\begin{array}{c}\text { Bending rigidity } \\
(\mu \mathrm{Nm})\end{array}$} \\
\hline & BT & AT & BTH & ATH & BT & AT & BTH & ATH & BT & AT & BTH & ATH \\
\hline & 1425.5 & 1621.2 & 1220.34 & 1410.12 & 204.42 & 181.34 & 200.23 & 178.98 & 187 & 294 & 200 & 300 \\
\hline & 1617.2 & 1720.2 & 1410.21 & 1547.27 & 213.43 & 187.78 & 204.45 & 184.22 & 211 & 303 & 228 & 307 \\
\hline & 1635.3 & 1789.9 & 1420.10 & 1549.22 & 215.67 & 187.67 & 210.26 & 183.26 & 211 & 305 & 226 & 310 \\
\hline & 1712.2 & 1821.4 & 1545.23 & 1658.47 & 203.78 & 194.89 & 199.32 & 190.78 & 223 & 293 & 235 & 300 \\
\hline & 1454.7 & 1659.5 & 1245.10 & 1469.20 & 183.89 & 169.21 & 178.96 & 161.45 & 190 & 273 & 205 & 280 \\
\hline & 1522.2 & 1728.6 & 1322.89 & 1536.23 & 188.45 & 161.66 & 180.23 & 155.58 & 197 & 278 & 211 & 288 \\
\hline & 1410.5 & 1578.7 & 1245.55 & 1389.36 & 192.67 & 170.67 & 185.69 & 162.24 & 191 & 278 & 208 & 280 \\
\hline & 1534.4 & 1789.9 & 1332.45 & 1589.36 & 187.67 & 172.73 & 180.23 & 165.89 & 197 & 277 & 215 & 282 \\
\hline & 1693.8 & 1822.4 & 1489.59 & 1635.78 & 201.89 & 193.90 & 195.78 & 184.78 & 207 & 283 & 219 & 288 \\
\hline & 1456.9 & 1547.2 & 1278.36 & 1345.25 & 191.34 & 168.45 & 182.36 & 162.45 & 190 & 275 & 204 & 281 \\
\hline & 1447.1 & 1549.4 & 1274.32 & 1345.89 & 192.43 & 170.23 & 183.54 & 161.23 & 189 & 272 & 202 & 278 \\
\hline & 1456.3 & 1687.3 & 1233.36 & 1458.36 & 206.22 & 172.56 & 198.58 & 189.22 & 191 & 296 & 204 & 302 \\
\hline
\end{tabular}

and can easily flatten, thereby reducing both inter and intra yarn porosity. Moreover, any increase in hairiness will cause air permeability to decrease. The hairiness of hand-spun yarn was higher than that of machine-spun yarn, resulting in the higher air permeability of fabric with machine-spun yarn as a weft.

Table 4 illustrates that the dissolution of one component resulted in a lower value of air permeability for treated fabrics than for untreated fabric. The air permeability of fabric was closely correlated with inter yarn porosity. Both intra and inter yarn porosity was affected by yarn flattening or deformation in

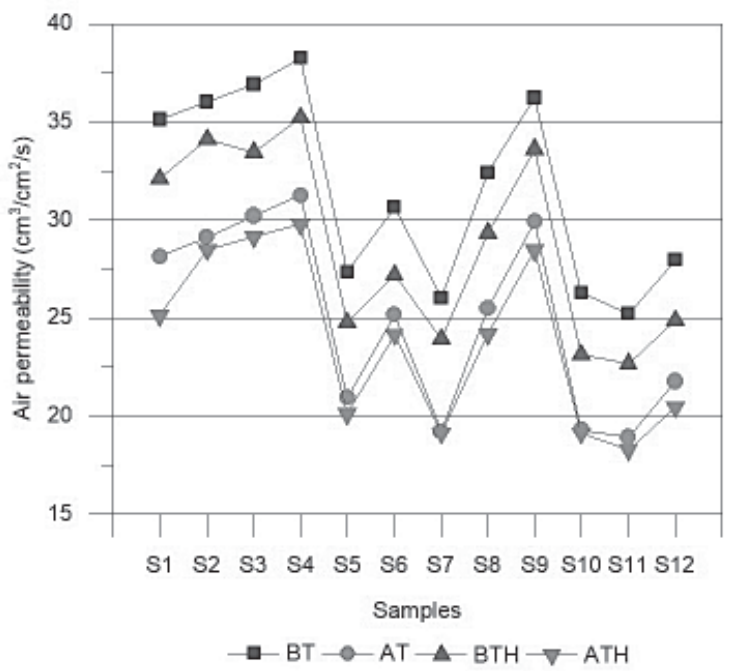

Figure 7: Air permeability of fabrics the fabric due to yarn compressibility. After the dissolution of the PVAL component, there was an increase in both yarn and fabric compressibility, which might have led to yarn flattening or fabric deformation. This ultimately reduced the air permeability of treated fabric.

\section{Water vapour permeability}

It is evident from Figure 8 that fabric containing hand-spun yarn as a weft exhibited lower water vapour permeability than fabric with machine-spun yarn as a weft. The water vapour permeability of fabric depends on the rate of diffusion. The irregular structure of hand-spun yarn could lead to a reduction in the diffusion rate, resulting in the reduced water vapour permeability of fabric.

Experimental results for the water vapour permeability of fabrics before and after treatment are presented in Table 4, which shows that, after the dissolution of the PVAL component, treated fabric exhibited a higher water vapour permeability than untreated fabric. The transfer of vapour through fabric depends on diffusion. The rate of diffusion from fabric depends on the pores/voids created in the structure by the dissolution of the PVAL component from a blended yarn. After the dissolution of the PVAL component, pores were created in the yarn structure, which resulted in the better transfer of water vapours through the diffusion process from one side of fabrics to other 
through pores within the structure, resulting in a higher value of water vapour permeability for treated fabric.

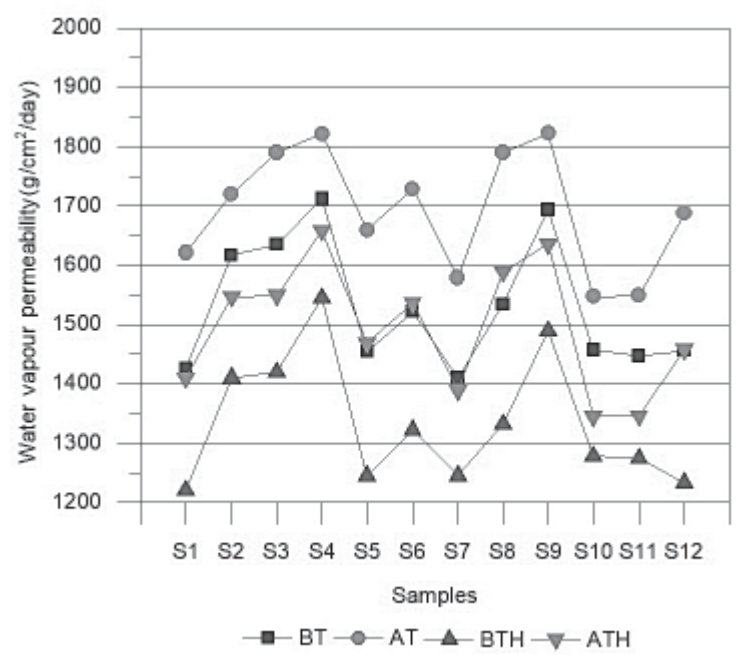

Figure 8: Water vapour permeability of fabrics

\section{Bending rigidity}

Fabric bending rigidity is an important parameter that can influence the handling and comfort of textile material. It is evident from Figure 9 that fabric with hand-spun yarn as a weft exhibited a lower bending rigidity than fabric with machine-spun yarn as a weft. Hand-spun yarn is softer and more pliable than machine-spun yarn. Fabric from machine-spun yarn is thus stiff.

Experimental results shown in Table 4 for untreated and treated fabric show a reduction in bending rigidity after the removal of the PVAL component

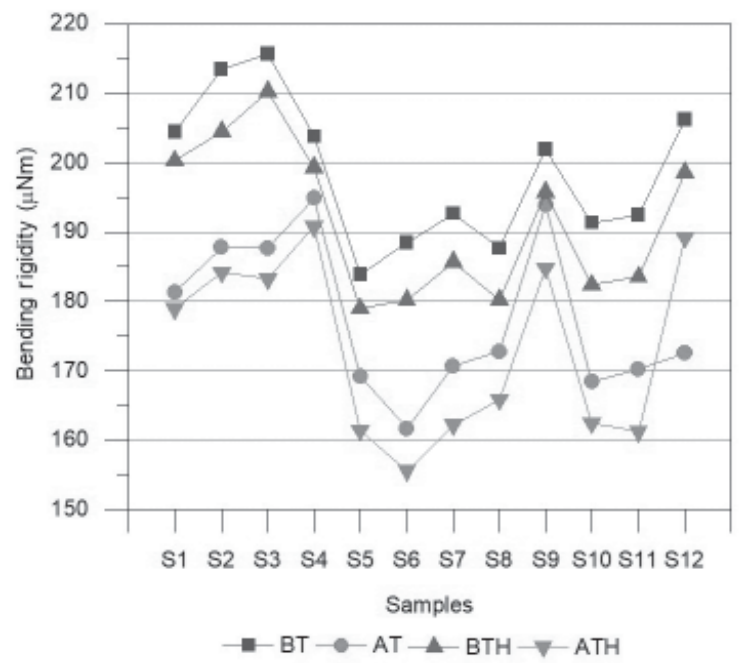

Figure 9: Bending rigidity of fabrics for both type of fabrics. This may be due to the creation of pores after the dissolution of the PVAL component, which ultimately enhanced fabric flexibility.

\section{Drying capacity}

It is evident from Figure 10 that the drying capacity of fabrics with hand-spun yarn as a weft is higher than that of fabric with machine-spun yarn as a weft. The porous nature of hand-spun yarn, which helps to absorb higher water content, resulted in a higher value of drying capacity than that of fabric with machine-spun yarn as a weft.

Results from Table 3 shows that the drying capacity value increased after the dissolution of the PVAL component, meaning that treated fabric will take more time to dry than untreated fabric. A structure that can absorb a larger mass of water will have a high drying capacity value, i.e. it will take longer to dry.

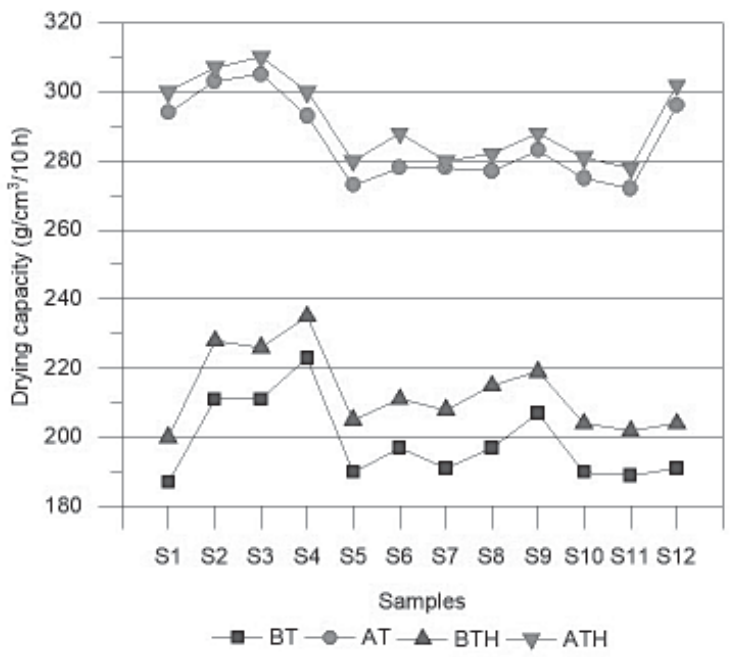

Figure 10: Drying capacity of fabrics

\subsection{Optimisation of fabric properties through desirability function}

Today, multi-response optimisation is a suitable method for overcoming the problem of conflicting responses of single response optimisation. Under this optimisation technique, the desired weight is given to all responses (equal weight in the present study) for varying values of input parameters to calculate the combined impact of all desirability responses. Parameters are set to enhance fabric quality according to customers' demands. Figures 11-14 show the curves of various factors (all six responses 
are given equal weights) for untreated fabric with machine-spun yarn as a weft, treated fabric with machine-spun yarn as a weft, untreated fabric with hand-spun yarn as a weft and treated fabric with hand-spun yarn as a weft respectively.

The parameters required to maximise overall desirability involve the percentages of fibres presented in Table 5 for different treated and untreated fabrics with machine-spun and hand-spun yarn as a weft.

Table 5: Percentage of fibres in weft with maximum desirability for different types of fabrics

\begin{tabular}{|l|c|c|c|}
\hline \multirow{2}{*}{ Fabric } & \multicolumn{3}{|c|}{ Fibres content in weft } \\
\cline { 2 - 4 } & $\begin{array}{c}\text { Polyester } \\
(\%)\end{array}$ & $\begin{array}{c}\text { Merino } \\
\text { wool (\%) }\end{array}$ & $\begin{array}{c}\text { PVAL } \\
(\%)\end{array}$ \\
\hline BT fabric & 20 & 70 & 10 \\
\hline AT fabric & 35 & 55 & 10 \\
\hline BTH fabric & 20 & 70 & 10 \\
\hline ATH fabric & 30 & 60 & 10 \\
\hline
\end{tabular}

The illustrations above (Figure $15 \mathrm{a}-\mathrm{d}$ ) show the overall desirability for BT, AT, BTH and ATH fabrics respectively. Harrington's rating system was used to interpret desirability values. The overall desirability value for BT fabric was 0.65 (Figure $15 \mathrm{a}$ ) and 0.73 for AT fabric (Figure $15 \mathrm{~b}$ ). It means that after the dissolution of PVAL, there was an improvement in overall desirability for fabric with machinespun yarn as a weft, while in the case of fabric with hand-spun yarn as a weft, the overall desirability value remained approximately the same (0.66 and 0.67 for BTH and ATH respectively) as shown in Figure $10 \mathrm{c}$ and $\mathrm{d}$ respectively. According to the Harrington standard, this threshold indicates that product quality is acceptable with regard to the specifications for BT, AT, BTH and ATH fabrics. The overall desirability bar graph for BT fabric (Figure $15 \mathrm{a}$ ) indicates that all responses are acceptable, but that the individual desirability values of bending rigidity (0.42) and drying capacity $(0.25)$ require some improvement. Effectively, for AT fabric, the individual desirability value for all responses was good, except for thermal resistance, which requires a small improvement according to the Harrington standard, as shown in Figure 15 b.

As evident in Figure 15 c, the individual desirability values for BTH fabric for different properties, such as air permeability, water vapour permeability, bending rigidity and compressibility, are $0.72,0.79$, 0.66 and 0.74 respectively, and are also acceptable according to the Harrington standard, while the individual desirability values for thermal resistance and drying capacity were 0.51 and 0.57 , which are also acceptable but still require some improvement.

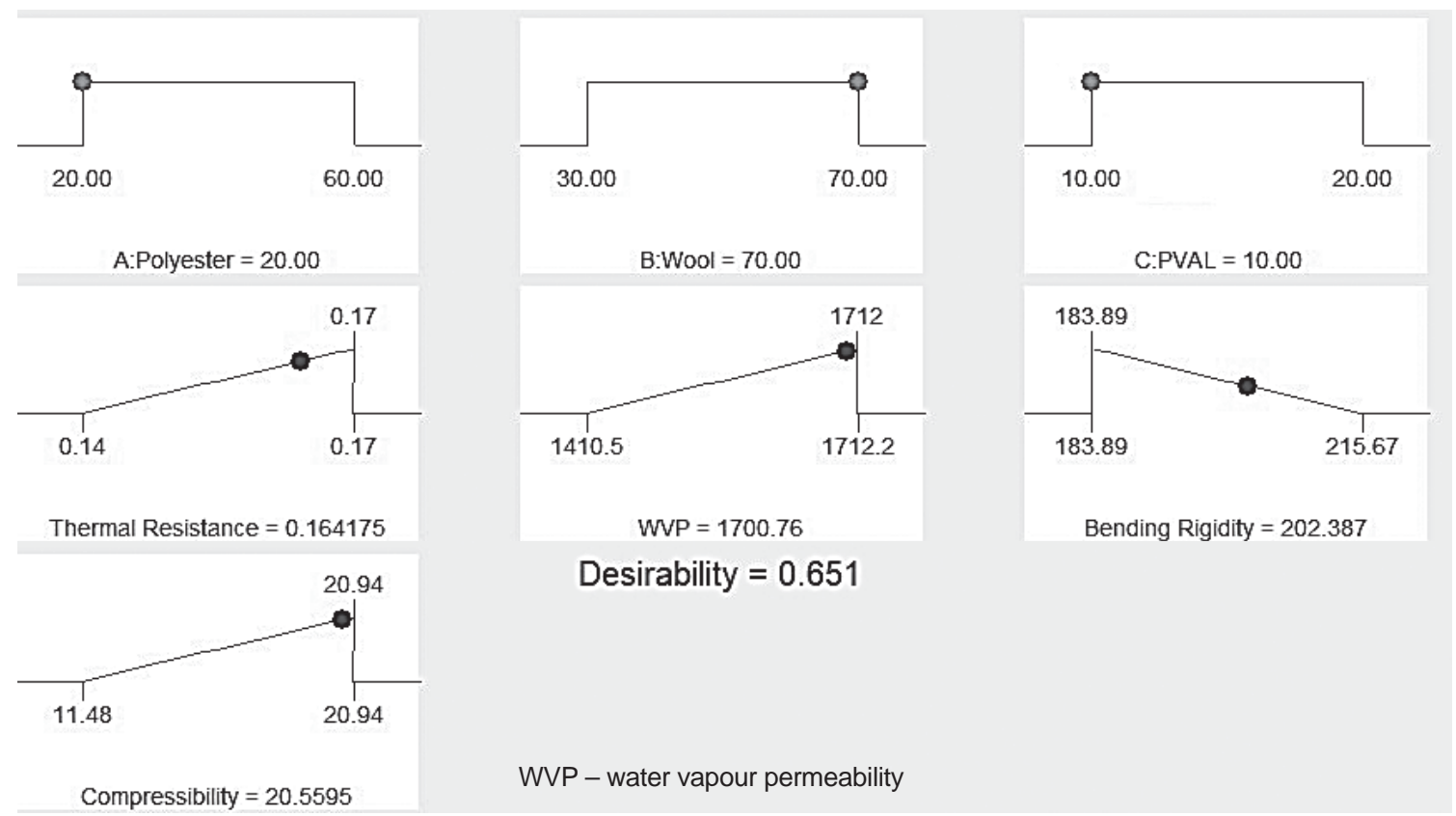

Figure 11: Curves of various factors for untreated fabric with machine-spun yarn as a weft 


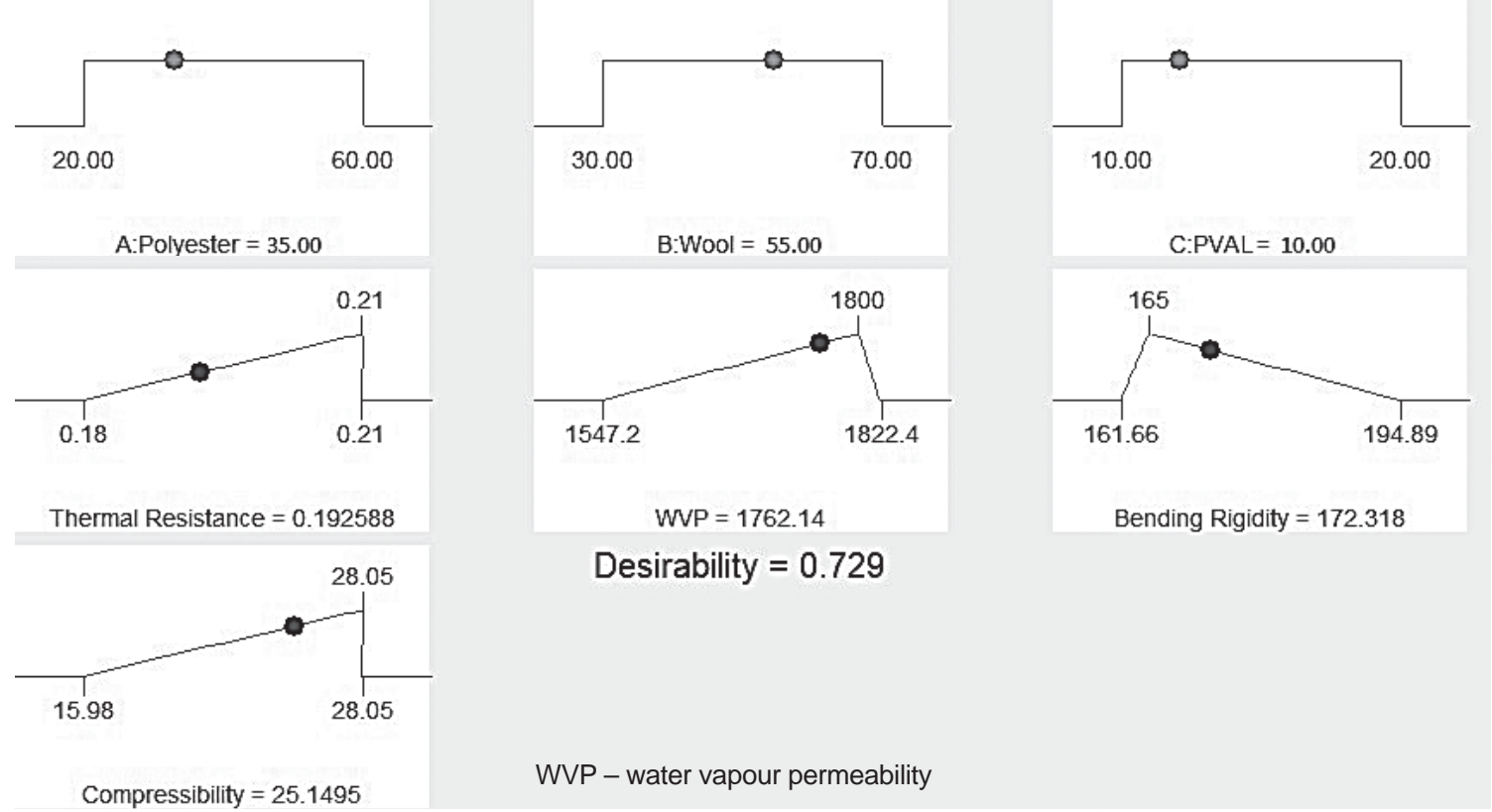

Figure 12: Curves of various factors for treated fabric with machine-spun yarn as a weft

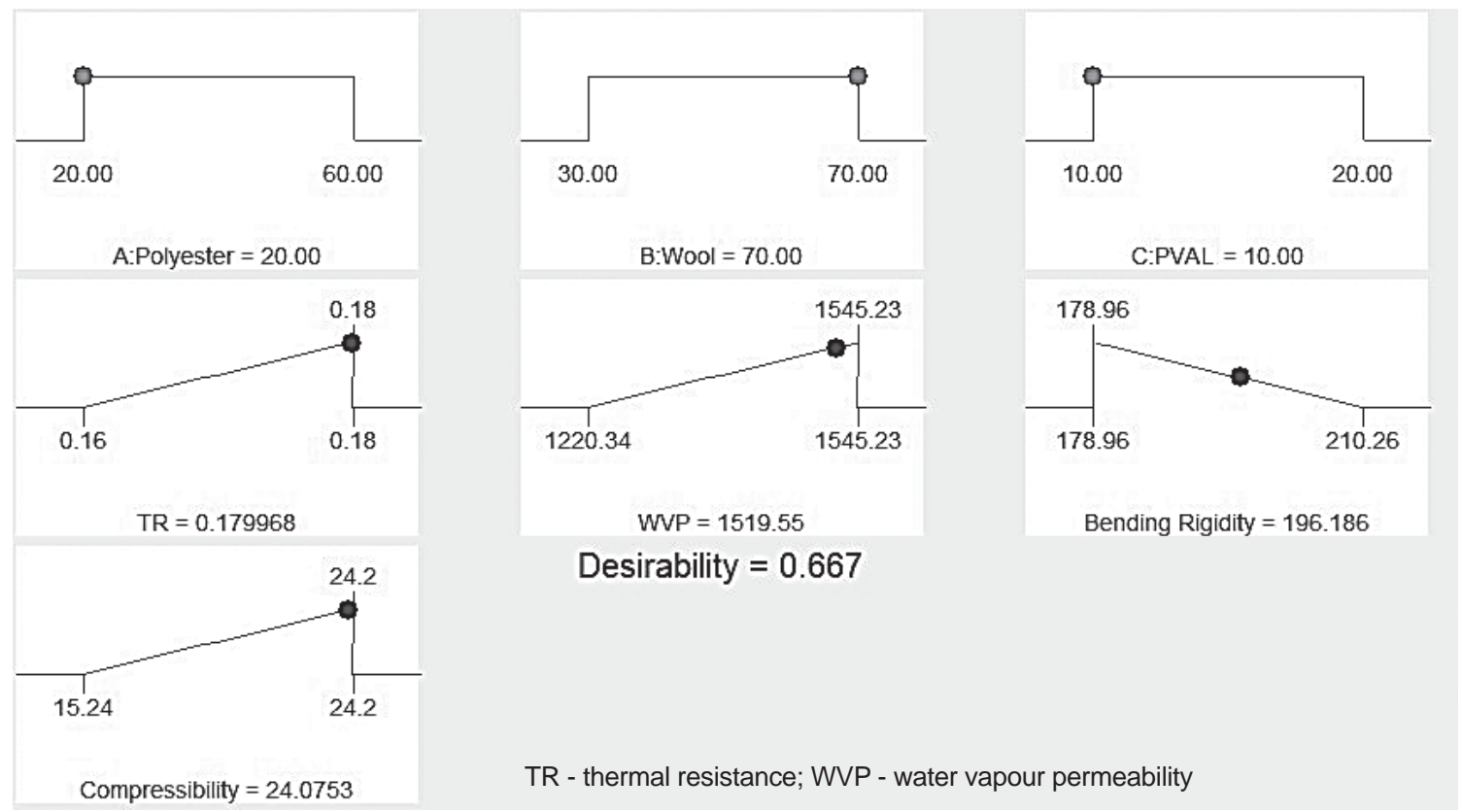

Figure 13: Curves of various factors for untreated fabric with hand-spun yarn as a weft

It is evident from Figure $15 \mathrm{~d}$ that all responses for ATH fabric exhibited excellent individual desirability values, except bending rigidity (0.49), which requires some improvement, and drying capacity (0.29), which requires more improvement.

\section{Conclusion}

This study addressed the effect of hand-spun and machine-spun weft yarns, before and after treatment, on different properties that influence the thermo-physiological behaviour of fabric. A fabric with hand-spun 


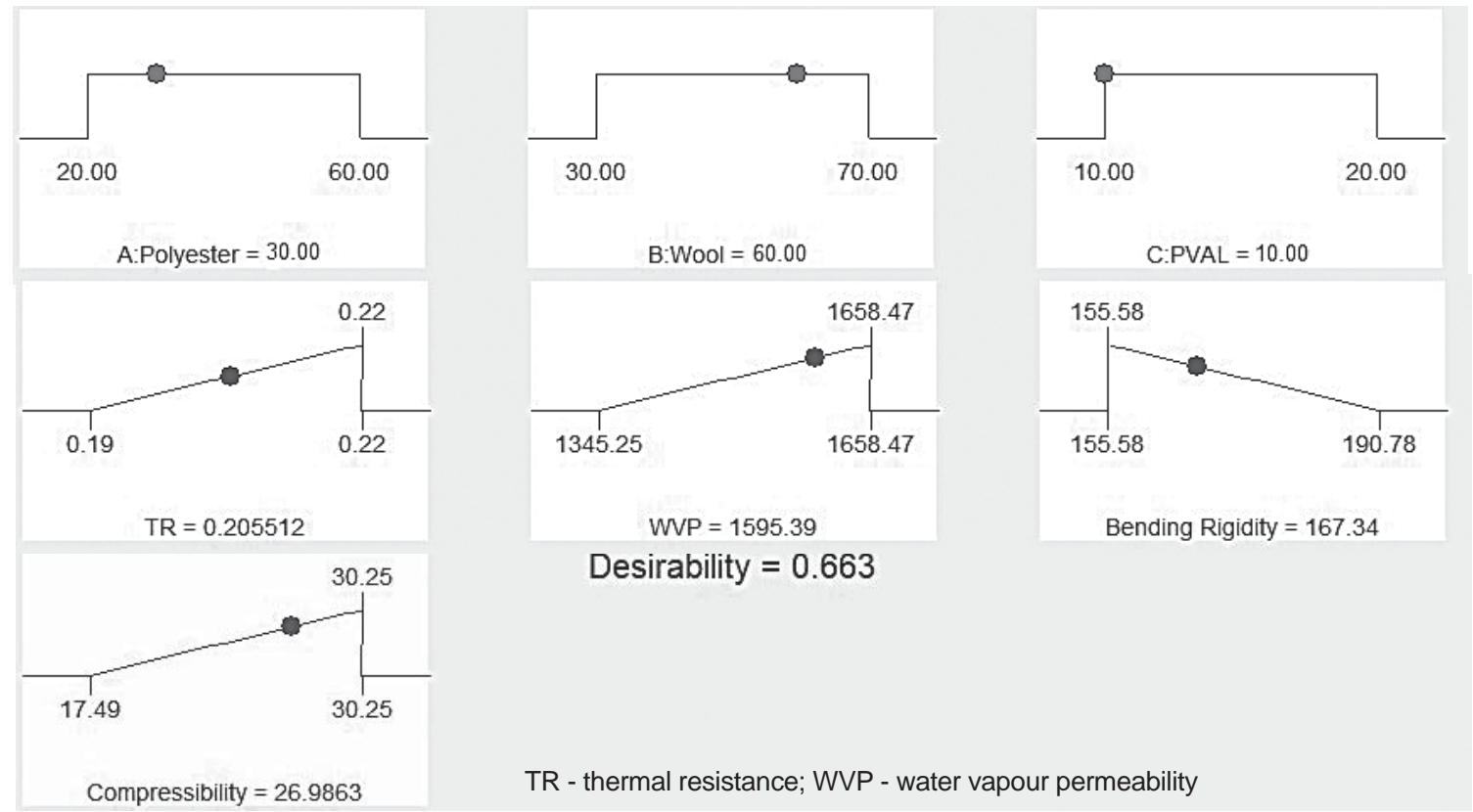

Figure 14: Curves of various factors for treated fabric with hand-spun yarn as a weft
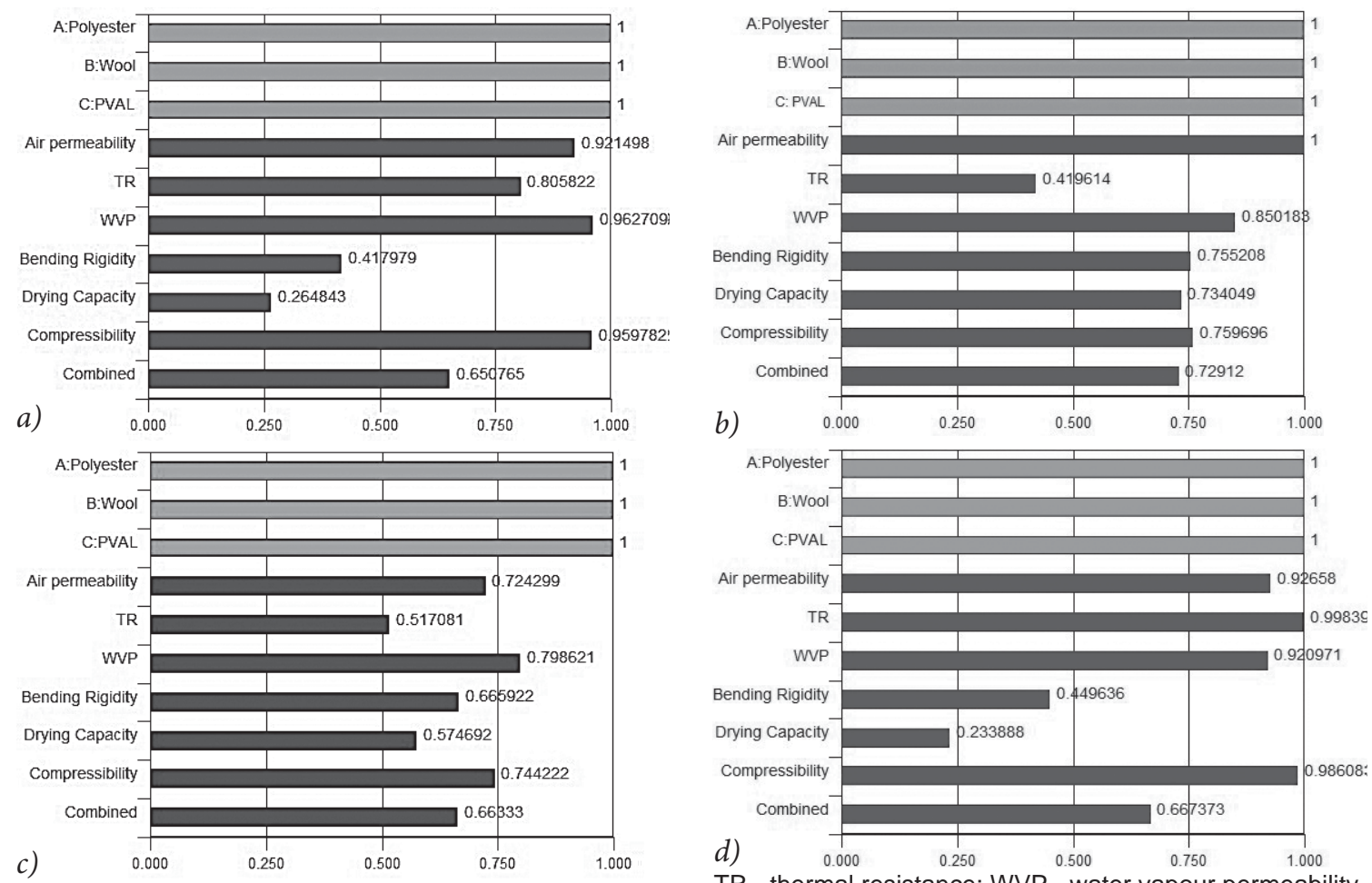

Figure 15: Overall desirability: a) BT, b) AT, c) BTH and d) ATH

yarn as a weft exhibited higher values of thermal resistance, bending rigidity, compressibility and drying capacity, while air permeability and water vapour permeability values were lower than fabrics with machine-spun yarn as a weft. After the dissolution of the PVAL component, thermal resistance, compressibility, water vapour permeability and drying capacity increased due to the creation of pores in 
the structure of both AT and ATH fabrics. Optimisation using a multi-response technique was also performed to identify the suitable percentage of fibres to achieve maximum desirability for customers for different fabric properties. Results for optimisation indicate that the same desirability $(0.65)$ can be achieved for both fabrics, either machine-spun or hand-spun, in the same blend composition. After the dissolution of PVAL, fibres in the case of AT fabrics exhibited an improved desirability value (0.73), as well as a change in the percentage of wool (55\%) in the blend composition relative to BT fabric (70\%). After the treatment of fabric with hand-spun yarn as weft, there was no change in desirability values, but there was a reduction in the percentage of wool $(60 \%)$ in the blend composition relative to BTH fabric (70\%).

\section{References}

1. SHARMA, N., KUMAR, P., BHATIA, D., SINHA, S.K. Moisture management behaviour of knitted fabric from structurally modified ring and vortex spun yarn. Journal of The Institution of Engineers (India): Series E, 2016, 97(2), 123-129, doi:10.1007/s40034-015-0075-z.

2. BHATIA, D., MALHOTRA, U., MALHOTRA, A. Impact on properties of woven fabric from structurally modified shoddy/wool blended worsted yarn. Journal of Fashion Technology \& Textile Engineering, 2016, 4(1), 1-6, doi: 10. 4172/2329-9568.1000128.

3. SINHA, S.K., KUMAR, P., GHOSH, S. Study on the packing density of structurally modified ring spun yarn. Fibres and Polymers, 2016, 17(11), 1898-1907, doi:10.1007/s12221-016-5940-y.

4. DAS, A., ISHTIAQUE, S.M., SINGH, R.P. Packing of micro-porous yarns. Part II : Optimization of fabric characteristics. Journal of the Textile Institute, 2009, 100(3), 207-217, doi:10.1080/ 00405000701559917.

5. CHANDRASEKARAN, V., SENTHILKUMAR, P., KARTHIK, T. Optimization of spinning parameters influencing the characteristics of structurally modified viscose yarn. Journal of the Textile Institute, 2016, 107(1), 50-63, doi:10.108 0/00405000.2014.1000017.

6. GHAREHAGHAJI, A.A., MOGHASSEM, A.R. Redistribution of fibres in the structure of hollow ring spun yarn. International Journal of En- gineering, Transactions B: Applications, 2009, 22(2), 197-204.

7. ERIKSSON, L., JOHANSSON, E., KETTANEHWOLD, N., WIKSTRÖM, C., WOLD, S. Design of experiments : principles and applications. Umeå : Umetrics Academy, 2000.

8. BAYKAL, P.D., BABAARSLAN, O., EROL, R. Prediction of strength and elongation properties of cotton/polyester-blended OE rotor yarns. Fibres \& Textiles in Eastern Europe, 2006, 14(1), 18-21.

9. PAL, S., GAURI, S.K. A desirability functionsbased approach for simultaneous optimization of quantitative and ordinal response variables in industrial processes. International Journal of Engineering, Science and Technology (IJEST), 2018, 10(1), 76-87, doi:10.4314/ijest.v10i1.6.

10. DERRINGER, G., SUICH, R. Simultaneous optimization of several response variables. Journal of Quality Technology, 1980, 12(4), 214-219. doi: 10.1080/00224065.1980.11980968.

11. VINING, G.G., MYERS, R.H. Combining taguchi and response surface philosophies : a dual response approach. Journal of Quality Technology, 1990, 22(1), 38-45, doi:10.1080/00224065.1990. 11979204.

12. KUMAR, P., BARUA, P.B., GAINDHAR, J.L. Quality optimization (multi-characteristics) through Taguchi's technique and utility concept. Quality and Reliability Engineering International, 2000, 16(6), 475-485, doi: 10.1002/1099-1638(200011/12)16:6<475::AID-QRE342>3.0.CO;2-0.

13. GHOSH, A., MAL, P., MAJUMDAR, A., BANERJEE, D. Optimization of knitted fabric comfort and UV protection using desirability function. Journal of Engineered Fibers and Fabrics, 2016, 11(4), 20-28, doi:10.1177/155892501601100404.

14. GUPTA, S.K., GOSWAMI, K.K., MAJUMDAR, A. Optimization of durability of Persian handknotted wool carpets by using desirability functions. Textile Research Journal, 2018, 88(1), 89-98, doi:10.1177/0040517516676056.

15. HADJ TAIEB, A., MSAHLI, S. Optimization of the knitted fabric quality by using multicriteria phenomenon tools. International Journal of Fiber and Textile Research, 2013, 3(4), 66-77.

16. ASIM, F, MAHMOOD, M, SIDDIQUI, M, A. Optimization of process parameters for simultaneous fixation of reactive printing and crease resistant finishing using desirability function. Journal of Textile and Apparel, Technology and Management, 2012, 7(3), 1-12. 